\title{
The Latvian Road to the Euro
}

\author{
Ewa Szymanik \\ University of Economics, Cracow, Poland
}

\begin{abstract}
The article presents the situation in Latvia ahead of the country's adoption of the euro by offering an analysis of the extent to which the country is prepared for the move and of general economic difficulties as well as indicating possible threats to its future development. The article talks about difficulties caused by the great unemployment connected with the specific economy of the country, political problems of the post-socialistic multinational country and steps done towards the fulfilling of all the convergence criteria. Its aim is to present the moments around the change of the currency which is done by the material's analysis because there are not enough statistical data for the mathematical analysis. It can be concluded that the adoption of the euro will probably be beneficial in the long run for Latvia's economy. The conclusions may be done by comparison with the situation of Estonia and its foreign trade with Poland which is shown in the article because there are a lot of similarities between the two Baltic countries.
\end{abstract}

Keywords: Latvia, euro, foreign trade, Poland

\section{Introduction}

Latvia became the 18th country adopting the euro when it introduced the common European currency on January 1, 2014. It was also the second Baltic state belonging to the large wave of extension to have decided to make the move, and another small economy representing a small part of the European Union's economic potential to have adopted the common currency.

Latvia decided to enter the euro zone during the still ongoing crisis, which had a significant impact on the small country. One should consider the path that it has trodden and the motivation that has guided its leaders in their bid to introduce the new currency, and finally endeavor to consider the impact that this situation will have on the trade between Latvia and Poland.

The aim of this article is to stay a base to the further observation of changes in the Latvian economy after taking the common value during crisis by the small country in the specific political situation. The period of the observation is too short for finding the good conclusions, that is why the analysis of the general situation was the mostly used method of researches.

\section{Economic Climate and Major Problems}

Because the Latvian entering the euro zone is a new problem, there are articles in newspapers rather than books. That is why the author decided not to make literature reviews but to write the problems in the European style and to mention all materials inside the article.

Ewa Szymanik, Ph.D., Cracow University of Economics, Cracow, Poland.

Correspondence concerning this article should be addressed to Ewa Szymanik, University of Economics, Rakowicka 27, 31-504, Cracow, Poland. E-mail: szymanie@uek.krakow.pl. 
With a population of mere two million inhabitants and an area of 64,559 square kilometers, Latvia is a small country with a predominance of industry over agriculture, a country heavily dependent on fuel imports (mainly from Russia) as well as exports, particularly of the wood products industry, as its main natural wealth is constituted of forests which occupy over 52\% of its territory (Encyklopedia PWN, 2014; Lotwa. Informator Ekonomiczny Ministerstwa Spraw Zagranicznych, 2014). Agricultural lands occupy 27\% of Latvia's area, and the main industries are exploitation of raw materials, electricity production, and production of means of transport, metal, electrical, furniture and food. Some revenue is also generated by tourism - this lowland country boasts numerous mineral springs, its Baltic beaches are its big asset as its national parks and Riga was declared as World Heritage Site by United Nations Educational, Scientific and Cultural Organization (UNESCO).

Latvia's basic statistics are presented in Table 1.

Table 1

Latvia-Main Economic Data

\begin{tabular}{lllllllll}
\hline & 2005 & 2006 & 2007 & 2008 & 2009 & 2010 & 2011 & 2012 \\
\hline GDP (mln EUR) & $12,927.8$ & $15,981.9$ & $21,026.5$ & $22,889.8$ & $18,521.3$ & $18,038.9$ & $20,211.3$ & $22,256.9$ \\
GDP growth (\%) & 10.1 & 11 & 10 & -2.8 & -17.7 & -1.3 & 5.3 & 5.2 \\
Unemployment rate (\%) & 9.1 & 6.9 & 6.1 & 7.7 & 17.5 & 19.5 & 16.2 & 15 \\
Inflation rate (\%) & 6.9 & 6.6 & 10.1 & 15.3 & 3.3 & -1.2 & 4.2 & 2.3 \\
Trade balance (mln EUR) & $-2,842$ & $-4,290$ & $-5,117$ & 6,897 & $-1,512$ & $-1,628$ & $-2,270$ & $-2,430$ \\
\hline
\end{tabular}

Source: Eurostat data.

Latvia is a relatively young country - its independence was declared on November 18, 1918. After World War II, it became one of the Soviet republics and regained independence on August 21, 1991, when the Latvian parliament declared independence and sovereignty (Poradnik przedsiębiorcy-Lotwa, 2014; Jańczak, 2009, p. 59). It also then decided to espouse the Euro-Atlantic and pro-Western direction of development. This decision was underpinned, among others, by its strong historical ties with Germany and the resulting social standpoint, although its varied ethnic composition, the adopted solutions and resultant problems all created serious complications. To illustrate these difficulties, one should only look at some demographic data.

Table 2 shows problems of the non-unification the Latvian society - Latvians are a little bit more than a half of the population. This results in not only the economical but also political problems. Not a lot of citizens identify themselves with their country and its pro-European policy. The next problem is, as everywhere in the poorer countries, an economical emigration which results in the fall of the population and all implications of there.

Due to their large number, the Russian sections of the population demand that their language become an official language in Latvia, which the Latvian authorities decline to acquiesce to, and this, in conjunction with restrictions on granting them full laws of the citizenship, also causes internal tension and pro-Russian political and economic sentiments of large sections of the population, which, in turn, have a bearing in part on the pace of economic development and low support for the introduction of the new currency.

These problems have not changed, however, the pro-Western course espoused by the country's government. From the beginning, the authorities adopted the following courses of action (Czarnecka, 2007, pp. 237-238): 
- developing cooperation with the other two Baltic states by creating a forum, which subsequently became the Baltic Council and in 1994 was transformed into a permanent body;

- establishing cooperation with the Nordic countries, especially Sweden;

- establishing integration with the European Union and North Atlantic Treaty Organization.

Table 2

Latvia's Ethnic Structure

\begin{tabular}{|c|c|c|c|c|c|c|c|c|c|}
\hline \multirow{2}{*}{ Nationality } & \multicolumn{2}{|c|}{1989} & \multicolumn{2}{|c|}{2000} & \multicolumn{2}{|c|}{2012} & \multicolumn{2}{|c|}{2013} & \multirow{2}{*}{$\begin{array}{l}\text { Difference between } 2013 \\
\text { and } 2000 \text { in thousands }\end{array}$} \\
\hline & number & $\%$ & number & $\%$ & number & $\%$ & number & $\%$ & \\
\hline Latvians & $1,387,757$ & 52 & $1,370,703$ & 57.7 & $1,245,246$ & 61 & $1,237,463$ & 61.1 & 133,240 (fall) \\
\hline Russians & 905,515 & 34 & 703,243 & 29.6 & 541,840 & 26.5 & 530,419 & 26.2 & 172,824 (fall) \\
\hline Belarusians & 119,702 & 4.5 & 97,150 & 4.1 & 72,011 & 3.5 & 70,273 & 3.5 & 26,877 (fall) \\
\hline Ukrainians & 92,101 & 3.5 & 63,644 & 2.7 & 47,495 & 2.3 & 46,335 & 2.3 & 17,309 (fall) \\
\hline Poles & 60,416 & 2.3 & 59,505 & 2.5 & 45,634 & 2.2 & 44,457 & 2.2 & 15,048 (fall) \\
\hline Lithuanians & 34,630 & 1.3 & 33,430 & 1.4 & 26,138 & 1.3 & 25,593 & 1.3 & 7,837 (fall) \\
\hline Gipsies & 7,044 & 0.3 & 8,205 & 0.3 & 6,106 & 0.3 & 5,906 & 0.3 & 2,299 (fall) \\
\hline Jews & 22,897 & 0.9 & 10,385 & 0.4 & 5,986 & 0.3 & 5,761 & 0.3 & 225 (fall) \\
\hline Germans & 3,783 & 0.1 & 3,465 & 0.1 & 2,870 & 0.1 & 2,782 & 0.1 & 683 (fall) \\
\hline Estonians & 3,312 & 0.1 & 2,652 & 0.1 & 1,999 & 0.1 & 1,938 & 0.1 & 714 (fall) \\
\hline Other & 29,410 & 1 & 25,001 & 1.2 & 49,488 & 2.4 & 52,898 & 2.6 & 27,897 (growth) \\
\hline All population & $2,666,567$ & 100 & $2,377,383$ & 100 & $2,044,813$ & 100 & $2,023,825$ & 100 & 353,558 (fall) \\
\hline
\end{tabular}

Source: Latvijas Statistika, resident population by ethnicity at the beginning of the year from http://www.csb.gov.lv/ and the author's own counting.

The country has also undertaken a series of economic reforms that would lead to the attainment of these objectives. They were accelerated by the accession talks with the European Union and negotiations with the World Trade Organization (Jańczak, 2009, pp. 63-67; Makowski, 2010, pp. 222-270). This stage was characterized by economic recovery, strengthening and consolidation of market institutions, the creation of new entities, restructuring of the economy and development of the banking and financial services.

Preparations for European Union membership brought a measurable result - the Russian economic crisis did not affect Latvia as deeply as other Baltic states. After reaching its low in 1999, Gross Domestic Product (GDP) growth began to rise. The GDP in 1996-2003 increased by over 50\%, achieving an average growth rate of about $7 \%$ per annum and was almost twice higher than in the European Union (Lotwa. Przewodnik dla przedsiębiorców, 2004, p. 21), so it can be said that the period of economic transformation was a success, as confirmed by reports prepared by international institutions, such as the World Competitiveness Yearbook 2004 or the Global Competitiveness Report 2005, which are the representative sources of the knowledge.

The Latvian economy was one of the fastest growing in the European Union. In 2007, the economy grew over 10\% (Lotewski rzqd przejmuje jeden z największych banków, 2008), but the following year saw a significant slowdown - in the third quarter of 2008, the country's GDP fell by $4.6 \%$ (Baj, 2008), and 2.8\% in the whole of 2008. The crisis reached its peak next year when the economy declined by a record $17.7 \%$, which meant that in 2008-2010 the combined GDP decreased by 21\%. Latvia asked for financial assistance from the International Monetary Fund (IMF) and the World Bank, and received it, so that in the next year, the rate of decline was arrested at 1.3\%, and 2011 saw a GDP increase of 5.3\%. This trend continued also in 2012-GDP growth reached 5.2\% and was the highest in the whole of the European Union. It is estimated that 2013 ended 
with a slower growth rate of four percent, and that this slower pace is set to continue in the subsequent years (4.1\% in 2014 and $4.2 \%$ in 2015), which may be due not so much to slower growth as to simple mathematical relationships. It should also be noted that this growth will also depend on the condition of European Union economies.

The main factor behind Latvian GDP growth was exports whose growth during the period from January to September 2011 amounted to $31.38 \%$, which was also associated with a gradual reduction in the adverse balance of foreign trade (Poradnik przedsiębiorcy — Lotwa, 2014). This trend continued in 2012 when a further increase in trade was reported. Exports reached a growth rate of 15\%, while imports grew $12.7 \%$ (Eotwa. Informator Ekonomiczny Ministerstwa Spraw Zagranicznych, 2014). All rating agencies raised Latvia's credit rating, which allowed Latvia to completely pay off its debt to the IMF.

This improvement of the economic situation was the result of drastic budget cuts. Even then, Latvia began to grow and increased aid to the unemployed and the poor. Despite high unemployment, economic indicators began to gradually improve and, as mentioned above, in the second half of 2010, Latvia saw the beginning of economic growth. It was connected with the improvement of the situation in the euro zone. Currently, Latvia continues to be growing fast and pushes on with structural reforms aiming to improve productivity and competitiveness.

The rate of inflation also changed. It is worth noting that after Latvia's accession to the European Union, its inflation gradually increased, strongly accelerating in 2007. The growth was successfully checked in 2009, and 2010 even witnessed a fall of $1.2 \%$ in prices. It reappeared, however, in 2011 when it reached $4.2 \%$, only to slow to $2.3 \%$ in 2012 and $1.5 \%$ in the first quarter of 2013, and showed clear signs of a slowdown in the coming months, to $0.3 \%$ in October 2013 (Latvijas Statistika, 2011). The persistence of a high inflation rate was the result of adjustments of the Latvian economy to price relations in the European Union, and later was due to the economic crisis and the fact that the fixing of the exchange rate against the euro made economic stabilization difficult.

It may be noted that the main trends underlying the Latvian economy are: high GDP growth, decreasing unemployment, clearly easing inflation, strong growth in foreign trade, and economic stabilization. Exports grew, while the growth rate of imports fell, which is important for the country, which, as already mentioned, is highly dependent on foreign trade. A summary of results for the recent years is presented in Table 3 .

Table 3

Latvia's Exports and Imports in 2011-2013 (in Millions of Euros)

\begin{tabular}{lrcc}
\hline & 2011 & 2012 & $2013^{*}$ \\
\hline Total export & $8,535.8$ & $9,871.2$ & $9,228.2$ \\
EU-27 & $5,722.3$ & $6,859.8$ & $6,595.7$ \\
Total import & $10,983.2$ & $12,512.5$ & $11,471.8$ \\
EU-27 & $8,433.1$ & $9,675.6$ & $9,112.8$ \\
Export to Poland & 244.3 & 228.5 & 181.317 \\
Import from Poland & 843.2 & 981.4 & 961.148 \\
\hline
\end{tabular}

Note. * Data January to November of 2013. Source: Rocznik statystyczny handlu zagranicznego (2012, 2013) and author's own calculations based on http://www.csb.gov.lv.

As already mentioned, the situation of European Union countries is crucial for the development of the Latvian economy since most of its trading partners are European Union member states. The neighboring states 
of Lithuania and Estonia account for most of Latvia's foreign trade, with Russia ranked third, followed by Germany, Sweden, Poland, and Denmark (Poradnik przedsiębiorcy_Lotwa, 2014).

Poland is one of Latvia's major trading partners as shown in Table 3. In 2012, Poland's 6\% share in Latvian exports made it the fifth largest partner, while importation from Poland accounted for $8.5 \%$ of total imports, making Poland the fourth largest exporter to Latvia. In fact, however, the exchange is much higher as part of the turnover in trade is conducted by companies registered in Lithuania. In fact, Poland occupies the 2nd-3rd place among Latvian trading partners (Lotwa. Informator Ekonomiczny Ministerstwa Spraw Zagranicznych, 2014). Poland exports mechanical and electrical equipment (29\%), chemical products, articles of base metal and groceries, while it imports predominantly metal products, mineral products, wood products and mechanical and electrical equipment. Preliminary estimates for the previous year are also favorable - in the first quarter of 2013, the value of Polish exports amounted to 263.59 million euros (compared to 207.72 million in the corresponding period of 2012), while imports stood at 55.95 million (compared to 53.76 million euros in 2012), which means that Poland still occupied a sixth position high among Latvia's export partners, and the fourth in imports. The trade dynamics is also growing - in the reporting period they reached $122.12 \%$.

\section{Preparations for the Adoption of the Euro}

Latvian economy's strong dependence on foreign trade was certainly one of the most important factors behind the adoption of the euro. It is expected that with its introduction, the economy should grow by an additional $0.5 \%$ of GDP annually (Lotwa przechodzi na eurowalutę, 2014). So what did the preparations for this change look like?

Like Poland and many other countries, Latvia committed itself to adopt the euro after its accession to the European Union. The entry into the euro zone area is conditional upon the participation for at least two years in European Rate Mechanism (ERM) II and the fulfillment of the convergence criteria referred to article 122, paragraph two of the European Commission Treaty. Pursuant to the provisions of this article, at the request of a member state subject to a derogation, at least once every two years the European Commission and the European Central Bank should report to the Council of the European Union (in practice, the European Commission submits a report every six months). Latvia made the request in May 2005. It entailed the adoption by the Latvian parliament of the "law on the introduction of the euro" and of the National Plan of Change of Currency (Retrieved from http://www.eiro.lv).

The first criterion that a candidate for the adoption of the euro must fulfill is the criterion of price stability, meaning that a member state has a sustainable level of price stability and the average rate of inflation in the year before the review does not exceed the inflation rate of the three member states with the most stable prices by more than 1.5 percentage points. The method of measuring inflation is set out in a specific regulation of the Council of the European Communities (Dz. U. L 257 from 27.10.1995; Dz. U. L 284 from 31.10.2003) ${ }^{1}$.

The Convergence Report (2013) in June determined the inflation rate for the reference period from May 2012 to April 2013. During the audited period, the countries with the best results were: Sweden (0.8\%), Latvia $(1.3 \%)$, and Ireland (1.6\%). Given the above, the inflation criterion was duly satisfied by Latvia.

The requirement of sustainability of the process implies that a satisfactory reduction in inflation must strictly conform rather to the behavior of initial costs and other factors affecting the structure of price formation

\footnotetext{
${ }^{1}$ Dz. U. L 257 from 27.10.1995 and Dz. U. L 284 from 31.10 .2003 are official government documents.
} 
than to the influence of temporary factors. Therefore, the study of convergence compliance involves estimation of inflation-prone factors and of medium-term outlook. Additionally, the assessment determines whether the country stands a chance of maintaining the reference value in the future (Dz. U. UE. L. 07.186.32) ${ }^{2}$.

In the longer term, consumer price inflation in Latvia revealed strong fluctuations, which was already indicated. Signs of severe overheating of the economy intensified in the second half of the last decade deepening macroeconomic imbalances and producing a deep crisis in 2008 (The Convergence Report, 2013, pp. 50-80). A sharp decline in the next year led to the improvement of the country's competitiveness and helped it to regain stability. The high increase in inflation is attributed to fluctuations in global commodity prices, which the country is dependent upon, as well as changes in indirect tax rates. In the last audit period, a decline in the inflation rate was also associated with the reduction in these rates, which could have been dictated by the desire to accelerate the fulfillment of the inflation criterion.

The second criterion, likewise met by Latvia, was the criterion of government budgetary position, i.e. reduction of the deficit below $3 \%$ of the GDP. According to the treaty requirements, the limit can only be exceeded for exceptional reasons and the excess must be temporary by nature or a high past rate is markedly reduced and approaching the required 3\%. Prior to the Report Latvia was affected by an European Union Council decision on the existence of an excessive deficit, although in the reference year of 2012, the negative balance was $1.2 \%$ of the GDP, i.e. it stayed markedly lower than the permissible ceiling. This level was achieved thanks to reforms in the public sector-employee salaries were significantly reduced and government spending was slashed. The effects of this policy are still felt in the society today-many Latvians have gone abroad in search of better wages (since 2007 the country has lost approximately $10 \%$ of its population) (Eotwa za chwile w strefie euro. Rzqd triumfuje, obywatele petni obaw, 2013).

In addition to reducing the budget deficit, the above-mentioned criterion also includes the ratio of public debt to GDP, which cannot exceed 60\% of GDP, and if it is higher, it should show a downward trend and edge at a satisfactory pace to the agreed mark. Latvian debt was reported at $40.7 \%$, i.e. significantly less than the reference, but according to forecasts by the end of 2013, it was set to increase to $43.2 \%$. The European Commission's recommendation applies to progress in fiscal consolidation and strict adherence to the adopted law on fiscal discipline.

The third criterion concerns exchange rate stability. The national currency must be stable, which means that it cannot be devalued in relation to the currencies of other European Union members or be the cause of serious tensions in the foreign exchange market for at least two years prior to the assessment.

As already mentioned, Latvia participated in ERM II since May 2, 2005. The standard fluctuation band is $\pm 15 \%$, but at the time of its accession Latvia's government unilaterally committed to maintain the Latvian lat (LVL) exchange rate fluctuation band of $\pm 1 \%$ around the central rate. This stringent policy was followed at all times, including the crisis period, even though it involved the use of financial assistance granted by the IMF and the European Central Bank (ECB). The assistance helped to reduce the lack of financial resilience of the economy and ease the upward pressure on the exchange rate, but the country' financial stability is still not satisfactory.

The fourth convergence criterion relates to the level of the long-term interest rate as measured on the basis of 10-year treasury bonds, the assessment of which in the year preceding may not exceed by more than two

\footnotetext{
${ }^{2}$ Dz. U. UE. L. 07.186.32 is the official government document.
} 
percentage points - average rate in force in three member states with the most stable prices. The calculated reference value for the twelve months to April 2013 stood at a total of 5.5\%.

Latvia satisfied this criterion, reporting a rate of 3.8\%. During the reference period, this rate decreased due to the improved macroeconomic situation and the state of public finances. Latvia's credit ratings also improved - during the period of the examination in June 2013, Standard \& Poor raised the rating by one degree to $\mathrm{BBB}+$, an increase of four grades on the non-investment grade level of BB in just three years.

However, low interest rates mean that loans will be cheap, which may raise concerns about the appearance of speculative bubbles caused by excessive bank activity. A statement by Latvia's ambassador in Poland, Kḷava indicated that he expected growth in investment lending, but believed in the importance of on-going financial supervision of banks to prevent destabilization of the national economy (Retrieved from www. polskieradio.pl).

Legal compliance is the fifth criterion. It involves the compatibility of national legislation, including the statutes of its national central bank, with Articles 108 and 109 of the European Commission Treaty and the Statute of the European System of Central Banks.

Latvian law meets these requirements, although the European Commission recommends the occasion of the first amendment to the Law on Latvijas Banka that is one of the provisions according to which the Latvian parliament exercises oversight over the central bank clarified.

Despite such good results, ECB's conclusion is rather pessimistic.

Although Latvia does not exceed the reference values, the sustainability of economic convergence in the long term causes concern. In the past, the country experienced business cycles with a very high amplitude and high volatility of macroeconomic indicators. Entry into the monetary union entails giving up its own monetary policy and exchange rate policy, which makes internal flexibility and resilience increasingly important. Thus, the durability of the economic situation depends on constant readiness - both on the part of the authorities and the society - to make the necessary adjustments to and reforms of policy measures for the protection of macroeconomic stability and competitiveness of the economy. (The Convergence Report, 2013, p. 53)

It is also worth noting that the introduction of the new currency in Latvia happened in the face of strong social opposition. According to surveys conducted by TNS, adoption of the euro in mid-2013 was opposed by as many as $60 \%$ of respondents (Lotwa w styczniu wejdzie do strefy euro. Wbrew wlasnym obywatelom, 2013), although a eurobarometer survey at the end of that year showed for the first time that the number of supporters of the currency predominated over the number of its opponents (yet TNS research still showed a predominance of eurosceptics). Over $80 \%$ of the people worried about price rises, which was to be prevented by the dual quotation of prices in lats and euros from October, which is to be mandatorily maintained until the end of June this year (Lotwa przechodzi na eurowalute, 2014; Lotwa za chwile w strefie euro. Rzad triumfuje, obywatele petni obaw, 2013).

Adoption of the euro means that Latvia assumes an obligation to co-finance the European Stability Mechanism under which aid is to be paid to indebted euro zone countries, and therefore support country like Greece, whose per capita income is one and a half times higher than Latvia's (one of the poorest European Union countries), which in itself borders on paradox.

Due to the aforementioned large Russian minority in the country, some people believe that the transition to the new currency has not only economic significance, but also geopolitical significance, as euroscepticism is tantamount to pro-Russian sentiments. Thus, the new currency is also viewed from a new and previously unfamiliar angle. 
In an interview for Radio RMF, Latvia's Prime Minister, Dombrovskis, emphasised that the introduction of the euro will also be beneficial for borrowers (Retrieved from www.rmf.fm). During the economic boom, the Latvian central bank raised interest rates in order to cool the economy so many people took loans in euros (about $80 \%$ ) to avoid paying high interest rates. This meant a fairly strong dependence on decisions made in Frankfurt by the European Central Bank, but also without exerting any influence on the same. Accession to the euro turned this situation around and Latvia partially gains the ability which makes its decisions.

\section{Conclusions}

It is difficult to formulate conclusions regarding the effects of the transition to the new currency after such a short time - rather than that the situation begs a number of questions. Undoubtedly, it will be necessary to continue monitoring how the euro will affect the Latvian economy-whether economists' predictions of increased economic stability, reduction in costs and elimination of transaction costs translating into GDP growth of $0.5 \%$ per year will come true or not. Perhaps it is possible due to the high growth rate, improvement of the economic situation of Latvia's main trading partners and consistent pursuit of reforms.

It gives a lot of doubts that the need for co-financing of the debt-ridden countries of South Europe-for an economy of Latvian size is a heavy burden. It may be that the associated costs exceed the benefits of the adoption of the single currency, which will further undermine this otherwise rather weak country economically. One should always remember that Latvia depends on foreign trade, which means that any disorder, especially in the case of trade with Russia, can seriously aggravate the difficulties. Latvia has found itself in a rather unhappy position - strengthening of closer links with the European Union can result in widely understandable sanctions from Russia, e.g. restrictions on fuel supply, which could seriously threaten the stability of the economy. On the other hand, Latvia is a small country, of little political importance for Russia, and moreover the second Baltic republic to adopt the euro. In this situation, Russia cannot be interested in additional restrictions, especially in the face of the situation in Ukraine.

Another issue that requires further monitoring is Polish trade relations with Latvia and the question whether the adoption of the euro will intensify the movement of goods between the two countries. Some help may come from tracking the situation in Estonia, which has been in the euro zone since 2011.

Table 4

Polish-Estonian Trade in 2010-2013 (in Millions of Euros)

\begin{tabular}{|c|c|c|c|c|c|c|c|c|}
\hline & \multicolumn{2}{|c|}{2010} & \multicolumn{2}{|c|}{2011} & \multicolumn{2}{|c|}{2012} & \multicolumn{2}{|c|}{$2013 *$} \\
\hline & 131.353 & 516.959 & 153.719 & 766.711 & 126.017 & 855.503 & 97.734 & 632.959 \\
\hline Estonia & 0.1 & 0.4 & 0.1 & 0.6 & 0.1 & 0.6 & - & - \\
\hline Estonia's share in Poland's foreign trade (in \%) & 5.5 & 1.5 & 6 & 1.3 & 6.2 & 1 & - & - \\
\hline Poland's share in Estonia's foreign trade (in \%) & 131.353 & 516.959 & 153.719 & 766.711 & 126.017 & 855.503 & 97.734 & 632.959 \\
\hline
\end{tabular}

Note. * Statistics for January to November, 2013. Source: Rocznik statystyczny handlu zagranicznego (2012, 2013) and author's own calculation based on Eurostat data.

The data presented in Table 4 above indicate that Poland's foreign trade with Estonia grew after the adoption of the single currency. This increase was systematic, although the share of total exchange did not change. Poland occupies a fairly important place in the Estonian economy, but a noticeable increase in trade may be due to a slow recovery from the crisis and the general improvement of the situation, not only from the adoption of the single European currency, which admittedly could have, but would not have to, contribute to 
growth in foreign trade. A premise in support of this thesis may be constituted by a systematic increase in Polish exports in the period. A cautious conclusion can be drawn from the fact that due to the importance of the Polish trade in Latvian trade, such an increase in Polish exports and a growth in imports proportional to the importance of the Latvian economy for Poland are highly possible. Probably further growth can be expected after the adoption of the euro by Lithuania due to the above mentioned agency of the country in trade.

Until now prices went up - an inflation rate was $0.4 \%$ but in consumer's opinion it was $10 \%$ (Euro na Lotwie: wdrożenie sukcesem. Ale ceny wzrosty, 2014). The same effect was observed in every country taken the new value but summarizing the above considerations, it can be concluded that the adoption of the euro will probably be beneficial in the long run for Latvia's economy.

\section{References}

Baj, L. (2008). Upadek bałtyckiego tygrysa. Warszawa: Gazeta Wyborcza.

Czarnecka, A. (2007). Droga państw byłego Bloku Wschodniego do akcesji do Unii Europejskiej, “Znaczenie”. Zeszyty Naukowe Zaktadu Europeistyki Wyższej Szkoty Informatyki i Zarzqdzania w Rzeszowie, 1, 237-238.

Economy of Latvia 2008-2014. Retrieved from http://www.eiro.lv

Encyklopedia PWN. (2014). Retrieved from http://encyklopedia.pwn.pl

Euro na Łotwie: wdrożenie sukcesem. Ale ceny wzrosty. (2014). Retrieved from http://epp.eurostat.ec.europa.eu

Jańczak, J. (2009). Droga Łotwy do członkostwa w Unii Europejskiej. In T. Szymczyński (Ed.), Negocjowanie granic: od "UE-15” do "UE-27”. Rozszerzenie wschodnie Unii Europejskiej, część druga-Grupa helsińska, Litwa, Lotwa, Stowacja. Malta, Butgaria, Rumunia w UE. Wydawnictwo Naukowe WNPiD UAM, Poznań, 5, 59-67.

Latvijas Statistika. (2011). On key provisional results of Population and Housing census 2011. Retrieved from http://www.csb.gov.lv/

Łotewski rzad przejmuje jeden z największych banków. (2008). Warszawa: Gazeta Wyborcza.

Łotwa przechodzi na eurowalutę. (2014). Warszawa: Gazeta Wyborcza.

Łotwa w styczniu wejdzie do strefy euro. Wbrew własnym obywatelom. (2013). Warszawa: Gazeta Wyborcza.

Łotwa za chwile w strefie euro. Rzad triumfuje, obywatele petni obaw. (2013). Warszawa: Gazeta Wyborcza.

Lotwa. Informator Ekonomiczny Ministerstwa Spraw Zagranicznych. (2014). Retrieved from http://www.informatorekonomiczny.msz.gov.pl/pl/europa/lotwa/?printMode=true

Łotwa. Przewodnik dla przedsiębiorców. Wydanie drugie rozszerzone z suplementem (maj 2005). (2004). Biuro Promocji Inwestycji i Technologii Organizacji Narodów Zjednoczonych ds (p. 21). Warszawa: Rozwoju Przemysłowego.

Main steps towards the euro area 2003-2013. Retrieved from http://www.eiro.lv

Makowski, Ł. (2010). System polityczny Łotwy i jego zwiazki ze sferq gospodarcza w dobie trzeciej fali demokratyzacji. In A. Marszałek (Ed.), Toruń, 222-270.

Polish Radio. (2013). An interview for the Polish Radio on December 28th, 2013. Retrieved from www. polskieradio.pl

Poradnik przedsiębiorcy - Lotwa. (2014). Retrieved from http://polska.trade.gov.pl

Radio RMF. (2014). An interview given on January 1st, 2014. Retrieved from www.rmf.fm

Rocznik statystyczny handlu zagranicznego. (2012). GUS.

Rocznik statystyczny handlu zagranicznego. (2013). GUS.

The Convergence Report. (2013). EBC (pp. 11-80). Retrieved from http://ec.europa.eu/economy_finance/publications/european_ economy/2013/pdf/ee3_en.pdf 